\title{
The effect of Psidium guajava Linn leaf extract on Candida albicans adherence and the transversal strength of acrylic resin
}

\author{
Amiyatun Naini ${ }^{1}$ and Sherman Salim ${ }^{2}$ \\ ${ }^{1}$ Department of Prosthodontic, Faculty of Dentistry Jember University, Jember - Indonesia \\ ${ }^{2}$ Department of Prosthodontic, Faculty of Dentistry Airlangga University, Surabaya - Indonesia
}

\begin{abstract}
Denture stomatitis is an inflammation of oral cavity due to removable denture wearing. Prevention of denture stomatitis can be effectively done by using mouth rinsing. Currently, Indonesian government is actively promoting traditional herbal medicine as an alternative medicine such as Psidium guajava Linn leaf which has an anti bacterial and anti fungal ability. The purpose of this study was to know the effective concentration and soaking duration to reduce Candida albicans without lowering transversal strength of acrylic resin. This experimental laboratory study was using heat cured acrylic resin plate without surface polishing. The concentration of Psidium guajava Linn leaf extract used in this study were 32\%, 34\%, 36\%, and 38\% respectively with 15 minutes, 30 minutes, 1 hour and 8 hours soaking duration. The transversal strength was measured in the same concentration with 2 days, 10 days and 60 days soaking duration. Sterile aquadest was used as control. Two direction ANOVA and LSD test were used in data analysis. The result showed significant difference in the number of Candida albicans colony among concentrations and soaking durations. Significant difference was also found in transversal strength among concentrations and soaking durations. It is concluded that the extract of Psidium guajava Linn leaf in $38 \%$ concentration with 8 hours soaking duration will lower the Candida albicans colony, whereas $38 \%$ concentration with 60 days soaking duration will lower the transversal strength but it is still above the standard value.
\end{abstract}

Key words: Psidium guajava Linn, acrylic resin, Candida albicans, transversal strength

Correspondence: Amiyatun Naini, c/o: Bagian Prostodonsia, Fakultas Kedokteran Gigi Universitas Jember. Jln. Kalimantan no. 37 Jember 68121, Indonesia. E-mail: amiyatunnaini_drg@yahoo.co.id

\section{INTRODUCTION}

In dentistry, up to the present time, denture base acrylic resin is still widely used besides denture base metal due to the relatively cheap price, easily manipulated, non toxic, easily reparation process when it is broken, and the small dimensional changes, ${ }^{1,2}$ while the disadvantages of acrylic resin are: porous, water absorption ability, easily fracture and broken. ${ }^{1}$

Denture is a good place for food debris accumulation. Denture base acrylic resin can be the place of stain, tartar and plaque accumulation. Accumulative plaque and food debris will increase the number of Candida albicans, therefore the endotoxin product can penetrate into mucous membrane and cause inflammation which is called denture stomatitis. ${ }^{3,4}$ It is found that $65 \%$ of elderly population are wearing denture, two thirds of $65 \%$ of denture users suffer from denture stomatitis. ${ }^{5-7}$

Prevention of denture stomatitis including pathogenic Candida albicans decreasing is very important. Candida albicans infection can be prevented by good cleaning. Removable denture cleaning can be done in two ways i.e mechanically and chemically. Mechanically cleaning can be done by brushing or using ultrasonic cleaner. Chemically cleaning can be done by soaking the denture into cleaning solution. The soaking duration in cleaning solution can be done for the whole night, 1 hour, 30 minutes or 15 minutes depending on the type of material. ${ }^{3}$ Denture cleaning solution is classified into five kinds i.e: alkaline peroxide, alkaline hypochlorite, inorganic acid, disinfectant and enzyme. $^{8}$

Due to relatively expensive price of chemical cleaning solution, traditional herb can be used as alternative cleaning solution for denture base acrylic resin. Some traditional herbal medicines such as leaf of Psidium guajava Linn ${ }^{9}$ can be used as denture cleaning solution and has an antiseptic and disinfectant function. The simple name of Psidium guajava Linn is Psidii folium. The chemical contents of the leaf are tannin, atsiri oil, cuercetine, 3-arabino piranosida, guayaverin, leukocianidine, anritoxide, avicularin, galate acid. The data taken from fitochemical laboratory showed that the mean concentration of galate acid was equivalent to $7.71 \%$, and $2.33 \%$ cuercetine of $96 \%$ ethanol extract. The result of pharmacological study showed that extract of Psidium guajava Linn leaf has an antimicrobial effect against Staphylococcus sp. ${ }^{10}$ The use of tannin is as an astringent, whereas atsiri oil and other active material as an antibacterial substance. Galate acid functions as antibacterial, antiviral, antifungal, anti inflammation, anti tumor, anti anaphilactic, anti mutagenic and it is usually used as astringent. ${ }^{11}$ Galate acid is including phenol group. Phenol can kill vegetative cell, fungi and bacteria forming spores by protein denaturation and lowering the surface tension, so that bacterial permeability will increase. ${ }^{12}$ If 
phenol group is used for acrylic resin soaking, either as cleaning or anti bacterial solution, the physical characteristic of denture base acrylic resin will be changed resulting in transversal strength decrease. ${ }^{13}$

According to Department of Health, Republic of Indonesia, extract of Psidium guajava Linn leaf in 30\%, $40 \%, 50 \%, 60 \%$ concentration will inhibit the growth of S. typhi, S. paratyphi A and S. paratyphi B. ${ }^{14} \mathrm{Up}$ to now there is no study on mycological effect of extract of Psidium guajava Linn leaf against Candida albicans, meanwhile acrylic resin can be adversely affected by phenol. Based on the above issue, a study on soaking duration of acrylic resin plate in various concentrations of Psidium guajava Linn leaf extract against Candida albicans and transversal strength is necessarily done.

\section{MATERIAL AND METHOD}

This study was experimental laboratory using the post test-only control group design. The samples were: $10 \times$ $10 \times 1 \mathrm{~mm}$ acrylic resin plate for Candida albicans test and $65 \times 10 \times 2.5 \mathrm{~mm}$ for transversal strength. ${ }^{15}$ The study was taken place in Laboratorium Dasar Bersama (LDB), Laboratory of Dental Technology, Fitochemical of Pharmacy Faculty, Laboratory of Microbiology Faculty of Dentistry Airlangga University.

The acrylic resin plates were prepared using $10 \times$ $10 \times 1 \mathrm{~mm}$ stippled wax. Samples for Candida albicans test were not polished. Brass plate master model, $65 \times 10 \times$ $2.5 \mathrm{~mm}$ in size was prepared for transversal strength test, then hard gypsum mold was made by mixing $100 \mathrm{gr}$ of gypsum powder and $24 \mathrm{ml}$ of water (based on manufacturer's recommendation). The mixture was manually steered for 15 seconds and put into the cuvet on the vibrator. Stippled wax was put on the gypsum and left for 15 minutes. The gypsum surface was covered by vaseline, then the upper cuvet was filled by gypsum on the vibrator. The wax was removed by pouring hot water until it was clean. The next step, mould was filled by acrylic resin i.e powder and acrylic resin liquid in $5.75 \mathrm{gr}: 2.5 \mathrm{ml}$ (based on manufacturer's recommendation) was prepared in porcelain bowl and steered at room temperature until it reached dough phase. The mould which was already covered by cold mould seal filled by acrylic resin dough. Cuvet was closed and pressed by hydrolic press in $22 \mathrm{~kg} / \mathrm{cm}^{2} \mathrm{Hg}$ pressure and then put into the curing unit. The process was done at $75^{\circ} \mathrm{C}$ for 90 minutes and continued at $100^{\circ} \mathrm{C}$ for 30 minutes. The curing process was completed and it was left to let it cool, finally the sample was removed from the cuvet.

The leaves for making Psidium guajava Linn extract were taken from a ten year old tree, located in Jl. Kawi 8, Jenggawah, Jember, and identified at the Laboratory of Botany Pharmacy-Pharmacognocy of Pharmacy Faculty, Airlangga University. First, fresh Psidium guajava Linn leaf was cleaned and dried in the room. Weighed $500 \mathrm{gr}$ and put into a crusher and given $1000 \mathrm{ml}$ of ethanol, being maserated for 72 hours and then filtered using Buchener funnel. The filtrate was evaporated using vacuum evaporator. Finally, 75 gr extract was obtained and this was $100 \%$ extract. The extract of Psidium guajava Linn leaf was weighed in $3.2 \mathrm{gr}, 3.4 \mathrm{gr}, 3.6 \mathrm{gr}, 3.8 \mathrm{gr}$ then dissolved in $10 \mathrm{ml}$ of sterile aquadest until $32 \%, 34 \%, 36 \%, 38 \%$ concentration of extract leaf was reached.

The acrylic resin plates were washed in running water for 48 hours, sterilization was done using autoclave at $121^{\circ} \mathrm{C}$ for 18 minutes, soaked in sterile saliva for 1 hour and washed by PBS twice, then, soaked in extract of Psidium guajava Linn leaf in 4 kinds of soaking duration (15 minute, 30 minute, 1 hour, 8 hour). In every concentration the soaking was repeated 7 times and aquadest was as control. The samples were washed by PBS twice, put into Sabouraud's broth followed by 30 seconds vortexed. Incubation was done in Saboroud's dextrose at $37^{\circ} \mathrm{C}$ for 48 hours, continued by counting the number of Candida albicans colony (cfu/ml).

For transversal strength test, all samples of acrylic resin plates $(65 \times 10 \times 2.5 \mathrm{~mm}$ in size $)$ soaked in aquadest for 48 hours, followed by soaking in extract of Psidium guajava Linn leaf $32 \%, 34 \%, 36 \%, 32 \%, 38 \%$ concentration for 2 days, 10 days, 30 days and 60 days. The replacement of soaking solution was done in every 24 hours, then washed by aquadest. The samples were dried before transversal strength test was done using autograph AG-10Te in cross head speed $1 / 10 \mathrm{~mm} / \mathrm{second}$. The distance between the two holders was $50 \mathrm{~mm}$. Statistical analysis was done using Two-Way ANOVA test, followed by LSD test.

\section{RESULT}

Table 1 shows the occurrence of Candida albicans on the surface of acrylic resin plate after being soaked in $32 \%$, $34 \%, 36 \%, 38 \%$ concentration of Psidium guajava Linn leaf extract for 15 minutes, 30 minutes, 1 hour and 8 hours.

Kolmogorof Smirnov test showed p > 0.05 which means the data had normal distribution. Levene test score was 1.411 and level of significance $=0.134(p>0.05)$ for concentration and soaking duration, which means the data was homogenous, therefore the test was continued by TwoWay ANOVA test.

ANOVA test showed a significant difference among the number of Candida albicans colony in acrylic resin plate which was soaked in 32\%, 34\%, 36\%, 38\% concentration of Psidium guajava Linn leaf extract in 15 minutes, 30 minutes, 1 hour and 8 hours $(\mathrm{p}<0,05)$. There is an interaction of significant difference in the number of Candida albicans colony between concentration and soaking duration. To know further about the difference among the sample groups, LSD test was done and the result can be seen in table 2 and 3 . 
Table 1. The mean of Candida colony on the surface of acrylic resin plate after being soaked in extract of Psidium guajava Linn leaf (cfu/0.1 ml)

\begin{tabular}{|c|c|c|c|c|c|c|c|c|}
\hline \multirow{3}{*}{ Group } & \multicolumn{8}{|c|}{ Soaking Duration } \\
\hline & \multicolumn{2}{|c|}{15 minutes } & \multicolumn{2}{|c|}{30 minutes } & \multicolumn{2}{|c|}{1 hour } & \multicolumn{2}{|c|}{8 hours } \\
\hline & $\bar{X}$ & $\mathrm{SD}$ & $\bar{X}$ & SD & $\bar{X}$ & SD & $\bar{X}$ & SD \\
\hline Control & 803.29 & 1.98 & 975.71 & 2.56 & 1021.43 & 5.22 & 1392.29 & 3.39 \\
\hline $32 \%$ & 776.57 & 1.90 & 629.71 & 4.19 & 565.00 & 3.21 & 67.33 & 2.99 \\
\hline $34 \%$ & 663.71 & 2.29 & 524.14 & 2.73 & 496.29 & 1.49 & 52.71 & 2.87 \\
\hline $36 \%$ & 545.57 & 3.90 & 400.86 & 4.26 & 281.27 & 3.40 & 36.86 & 5.55 \\
\hline $38 \%$ & 396.43 & 2.82 & 247.14 & 5.84 & 126.29 & 3.82 & 8.86 & 2.60 \\
\hline
\end{tabular}

Note: $\overline{\mathrm{X}}=$ Mean, $\mathrm{SD}=$ Standard deviation

Table 2. LSD test on the number of Candida albicans on the acrylic resin plate after being soaked in $32 \%, 34 \%, 36 \%, 38 \%$ concentration of Psidium guajava Linn leaf extract and control (cfu/0.1 ml)

\begin{tabular}{cccccc}
\hline Group & $32 \%$ & $34 \%$ & $36 \%$ & $38 \%$ & Control \\
\hline Control & $\mathrm{S}$ & $\mathrm{S}$ & $\mathrm{S}$ & $\mathrm{S}$ & - \\
$32 \%$ & $\mathrm{~S}$ & $\mathrm{~S}$ & $\mathrm{~S}$ & - & \\
$34 \%$ & $\mathrm{~S}$ & $\mathrm{~S}$ & - & & \\
$36 \%$ & $\mathrm{~S}$ & - & & & \\
$38 \%$ & - & & & & \\
\hline
\end{tabular}

Note: $\mathrm{S}=$ significant

Table 3. LSD test on the number of Candida albicans on the acrylic resin plate after being soaked in Psidium guajava linn leaf extract for 15 minutes, 30 minutes, 1 hour, 8 hours (cfu/ $0.1 \mathrm{ml}$ )

\begin{tabular}{lcccc}
\hline Group & $\begin{array}{c}15 \\
\text { minutes }\end{array}$ & $\begin{array}{c}30 \\
\text { minutes }\end{array}$ & 1 hour & 8 hours \\
\hline 8 hours & $\mathrm{S}$ & $\mathrm{S}$ & $\mathrm{S}$ & - \\
1 hour & $\mathrm{S}$ & $\mathrm{S}$ & - & \\
30 minutes & $\mathrm{S}$ & - & & \\
15 minutes & - & & & \\
\hline
\end{tabular}

Note: $\mathrm{S}$ = significant
There is significant difference among every concentration (32\%, 34\%, 36\%, 38\% and control). The increase of concentration will influence the number of Candida albicans colony and also the increase of soaking duration will show significant difference. The result of transversal strength acrylic resin plate will be shown in table 4 .

Kolmogorof Smirnov test showed p > 0.05 which means the data had normal distribution. Levene test score was 1.477 with level of significance 0.106 ( $p>0.05$ ) for concentration and soaking duration. It means the data was homogeneous. Therefore data analysis was done using Two-Way ANOVA test.

ANOVA test showed significant difference in transversal strength of acrylic resin plate soaked in $32 \%$,

Table 5. LSD test on transversal strength of acrylic resin soaked in $32 \%, 34 \%, 36 \%, 38 \%$ concentration of Psidium guajava Linn leaf extract and control $\left(\mathrm{N} / \mathrm{mm}^{2}\right)$

\begin{tabular}{clllll}
\hline Group & $32 \%$ & $34 \%$ & $36 \%$ & $38 \%$ & Control \\
\hline Control & S & S & S & NS & - \\
$32 \%$ & S & NS & NS & - & \\
$34 \%$ & NS & NS & - & & \\
$36 \%$ & NS & - & & & \\
$38 \%$ & - & & & & \\
\hline
\end{tabular}

Note: $\mathrm{S}=$ Significant, NS = Not Significant

Table 4. Mean of transversal strength of acrylic resin plate soaked in Psidium guajava Linn leaf extract $\left(\mathrm{N} / \mathrm{mm}^{2}\right)$

\begin{tabular}{|c|c|c|c|c|c|c|c|c|}
\hline \multirow{3}{*}{ Group } & \multicolumn{8}{|c|}{ Soaking Duration } \\
\hline & \multicolumn{2}{|c|}{2 days } & \multicolumn{2}{|c|}{10 days } & \multicolumn{2}{|c|}{30 days } & \multicolumn{2}{|c|}{60 days } \\
\hline & $\bar{X}$ & SD & $\bar{X}$ & SD & $\bar{X}$ & $\mathrm{SD}$ & $\bar{X}$ & SD \\
\hline Control & 182.31 & 9.76 & 167.14 & 4.17 & 163.80 & 6.36 & 159.34 & 9.92 \\
\hline $32 \%$ & 176.06 & 14.13 & 166.71 & 10.96 & 162.69 & 11.42 & 158.23 & 8.68 \\
\hline $34 \%$ & 170.06 & 7.36 & 166.03 & 5.89 & 161.57 & 10.77 & 157.11 & 11.42 \\
\hline $36 \%$ & 168.94 & 8.89 & 164.91 & 9.48 & 159.34 & 8.84 & 154.89 & 10.49 \\
\hline $38 \%$ & 168.26 & 9.92 & 163.80 & 6.37 & 158.23 & 9.78 & 151.54 & 7.61 \\
\hline
\end{tabular}

Note: $\overline{\mathrm{X}}=$ Mean, $\mathrm{SD}=$ Standard deviation 
Table 6. LSD test on transversal strength of acrylic resin plate soaked in Psidium guajava Linn leaf extract for 2 days, 10 days, 30 days, and 60 days $\left(\mathrm{N} / \mathrm{m}^{2}\right)$

\begin{tabular}{rcccc}
\hline Group & 2 days & 10 days & 30 days & 60 days \\
\hline 60 days & $\mathrm{S}$ & $\mathrm{S}$ & $\mathrm{S}$ & - \\
30 days & $\mathrm{S}$ & $\mathrm{S}$ & - & \\
10 days & $\mathrm{S}$ & - & & \\
2 days & - & & & \\
\hline
\end{tabular}

Note: $\mathrm{S}=$ Significant

34\%, 36\%, 38\% concentration of Psidium guajava Linn leaf extract and control with soaking duration 2 days, 10 days, 30 days and 60 days $(\mathrm{p}<0.05)$. There is interaction between concentration and soaking duration and LSD test was done (Table 5).

Significant difference was found among groups of $32 \%$, $34 \%, 36 \%, 38 \%$ concentration and control. The increase of concentration of Psidium guajava Linn leaf extract would decrease the transversal strength and also significant difference was found in soaking duration. The increase of soaking duration would decrease the transversal strength.

\section{DISCUSSION}

In this study, we used one of family herbal medicine plants which is frequently planted in the garden and easily grows i.e. Psidium guajava Linn (guava) which contains galate acid and atsiri oil as anti fungal. ${ }^{16}$ One of the forces received by acrylic denture base is transversal strength. Soaking of acrylic resin plate either in cleaning or anti bacterial solution can alter the basic character of denture base acrylic resin such as transversal strength. ${ }^{14}$

Statistical analysis Two-Way ANOVA test followed by LSD test shows that the higher the concentration of the extract and the longer the soaking duration resulting significant decreasing of the number of Candida albicans. On the contrary the lower concentration and the shorter the soaking duration, the number of Candida albicans will significantly increase. It is because extract of Psidium guajava Linn contains $96 \%$ of mean total of $7.71 \%$ galate acid. By the increase concentration, galate acid content would also increase including phenol in the extract solution so the anti Candida albicans will also increase. The duration of soaking was 15 minutes, 30 minutes, 1 hour, and 8 hours in extract of Psidium guajava Linn leaf will also decrease the number of Candida albicans colony because the increase of contact duration will increase the affectivity of anti microbial agent. The affectivity of material will be influenced by the concentration, duration and temperature. ${ }^{17}$ Galate acid including phenol group is used as anti bacterial, anti fungal, and can also be used as astringent. ${ }^{11}$ Chemical substance of galate acid has anti fungal activity against Candida albicans. ${ }^{16}$ Based on anti microbial function, phenol can kill cell of vegetative fungi and bacteria forming spore by protein denaturation and decrease the surface tension so the permeability of bacteria and fungi will increase. ${ }^{12}$

Transversal strength of acrylic resin plate resulted from Two-Way ANOVA and LSD test shows the higher the concentration and the lower the soaking duration, the transversal strength of acrylic resin plate will significantly decrease. On the contrary, the lower the concentration and the shorter the soaking duration, the transversal strength of acrylic resin plate will significantly increase. Long polyester polymer consisting of repeated methyl metacrilate unit with high polarity is the possible cause of acrylic resin degradation resulting in transversal strength decrease. Ester in acid environment will be hydrolyzed. If polymer is hydrolized, degradation will occur resulting in transversal strength decrease. ${ }^{2}$ Phenol content in guava leaf will cause stretching of intra molecular bind in which sooner or later can break intra molecular bind, so the transversal strength will decrease. ${ }^{18}$ The mean of the lowest transversal strength is in 60 day-soaking duration $\left(151.54 \mathrm{~N} / \mathrm{mm}^{2}\right)$. This value is much higher than recommended transversal strength of heat cured acrylic resin that is not less than $55 \mathrm{~N} / \mathrm{mm}^{2}{ }^{2}{ }^{16}$ The acrylic 2 days, 10 days, 30 days, and 60 days soaking duration of the acrylic resin plate is equal to 6 days, 1 month, 3 months, and 6 months use.

It is concluded that $38 \%$ concentration and 8 hour soaking duration will decrease the number of Candida albicans in acrylic resin plate. Thirty eight percent concentration and 60 days - soaking duration will decrease the transversal strength of acrylic resin plate but it was still above the standar value that is not less than $55 \mathrm{~N} / \mathrm{mm}^{2}$.

\section{REFERENCES}

1. Reisbick MH. Dental material in clinical dentistry. London: John Wright; 1982. p. 309-23.

2. Combe EC. Notes on dental material. $6^{\text {th }}$ ed Edinburg: Churchil Livingstone; 1992. p. 79-120.

3. Jorgensen BE. Material and method for cleaning denture. J Prosthet Dent 1979; 42: 619-22.

4. Samaranayake LP, Mc Courtie J, Mac Fartene TW. Factor affecting the in vitro adherence of Candida albicans to acrylic surface. Arch Oral Biol 1980; 25:611-5.

5. Segal E, Lehrman O, Dayan D. Adherence in vitro of various Candida spesies to acrylic surface. Oral Surg Oral Med Oral Pathol 1988; 66:670-3.

6. Lapocino AM, Wathen WF. Oral Candida infection and denture stomatitis: a comprehensive review. J Am Dent Assoc 992; 123:446-51.

7. Kulak Y, Arikan A. Aetiology of denture stomatitis. J of Mamara University Dental Faculty 1993; 1:307-14.

8. Davenport JC. The oral distribution of Candida albicans in denture stomatitis. Brit Dent J 1970; 129:151-7.

9. Moore TC, De Smith, Kenny GE. Sanitazion of denture by several denture hygiene methods. J Prosthet Dent 1984; 52:158-63.

10. Departemen Kesehatan RI. Pemanfatan Tanaman Obat. Edisi III. Jakarta: Dep. Kes. RI; 1983. p. 82-3.

11. Bambang. Tampil percaya diri dengan ramuan tradisional. Edisi II Jakarta: Penebar Swadaya; 2000. p. 70-1.

12. Jeffrey BH, Herbert B, Gerard PM. Phytochemical. Dictionary. $2^{\text {nd }}$ ed. France: Taylor \& Francis Ltd; 1999. p. 501. 
13. Shen C, Javid NS, Colaizzi FA. The effect of glutaraldehyde base disinfectants on denture base resin. J Prosthet Dent 1989; 61:583-9.

14. Departemen Kesehatan RI. Penelitian tanaman obat di beberapa Perguruan Tinggi di Indonesia, Badan Penelitian dan Pengembangan Kesehatan Pusat Penelitian dan Pengembangan Farmasi. Jakarta. 2000; p. 240.

15. Devi R. The transverse strength of acrylic after Coleus amboinicus, Lour extract solution immersion. Dent J (Majalah Kedokteran Gigi) 2006; 39(4):156-60.
16. Asad T, Watkinson AC, Huggest R. The Effect of desinfection procedures on flexural properties of denture base acrylic resins. J Prosthet Dent. 1992; 68:194-5.

17. Li XC, Jacob MR, Pasco DS, Elsobly HN, Nimrod AC, Walker LA, Clark AM. Phenolic compounds from Miconia myriantha inhibiting Candida aspartic proteases. J Nat Pred 2001; 64(10):1282-5.

18. Siswandono, Soekarjo B. Kimia medisinal. Cetakan I. Surabaya: Airlangga University Press; 1995. p. 247-8. 